\title{
UNTYING THE IMMIGRANT TONGUE: WHITMAN AND THE "AMERICANIZATION" OF ANZIA YEZIERSKA
}

\author{
WENDY R. KATZ
}

FOR THE JEWISH-AMERICAN immigrant writer Anzia Yezierska (1881?1970), the world of language - far more than that of the factory, the settlement house, or the department store-helped to shape the sense of her American self. As a Jewish woman attracted to the freedom and independence promised by her new country, Yezierska looked well beyond rabbinical sway to a secular and specifically cultural authority. In the literature of her new country, it seems, she found a way to balance her aspirations as a writer with her profound desire to become an American. Writing was bound up with articulating the shape of her American identity, and Walt Whitman was instrumental in this process of literary "Americanization."

Yezierska, who left her native village near Warsaw in the 1890 s, is not the only Jewish immigrant with literary interests and aspirations who was drawn to Whitman and found sustenance in his unconventional style and egalitarian politics. Emma Goldman (1869-1940), the Russian-born anarchist and feminist activist who immigrated to Rochester, New York, in 1885, lectured on Whitman and published selections from his poetry in her magazine Mother Earth, which she initiated in 1906. According to her biographer Alice Wexler, Goldman was attracted to Whitman's anti-authoritarianism and his position in "the America of the rebels and radicals, the dreamers and dissenters."1 Whitman's place in a tradition of dissent also attracted writer Michael Gold (1894-1967), the son of immigrant Jewish parents and another radical, whose "Ode to Walt Whitman" entreats the "new pioneers" to "sing . . . with Father Walt." 2 Gold enlists Whitman in his vision of a future under communism for both Irish and Jewish immigrants, the fulfilment of the "Lenin dreams of the kelleys and the greenbaums / Deep in the gangrened basements / Where Walt Whitman's America / Aches to be born" (171).

Critic Irving Howe, in World of Our Fathers, writes of the influence of Whitman on two Jewish literary groups, the pre-World War I Di Yunge and the post-war In Zikh poets. For the former, Howe attributes Whitman's influence to the poet's disposition and temper, and, for the 
latter, to Whitman's literary technique: “One American poet, Walt Whitman, did have an impact on Di Yunge, not particularly for his meters or diction, but for his expansiveness of spirit and egalitarian values"; 3 while the modernist In Zikh poets, Howe maintains, were interested in free verse and thus more affected by Whitman's style (440). A rather unusual and slightly later example of Whitman's influence in immigrant circles is suggested by Thomas J. Ferraro, who, in Ethnic Passages, Literary Immigrants in Twentieth-Century America, looks at the attraction of Whitman for a second-generation albeit decidedly non-Jewish writer, Henry Miller. Miller lived in Brooklyn, was the grandson of Protestant German immigrants and, Ferraro argues, wrote in a literary milieu of the "down-and-out ethnic working class depicted in many of the most sophisticated of American texts of the 1930s, texts authored by writers from the full range of immigrant backgrounds." When Miller went to Paris in 1930, he took his copy of Leaves of Grass, obsessed by Whitman's lines that appeared to him to have a special affinity: "My tongue, every atom of my blood form'd from this soil, this air, / Born here of parents born here from parents the same, and their parents the same, / I, now thirty-seven years old in perfect health begin." Ferraro traces this passage in Miller's autobiographical narrative, "The Tailor's Shop," the piece cited as grounds for placing Miller in the ranks of immigrant writers, and examines the various ways that Miller imitates Whitman, "another Brooklyn boy who could make poetry out of street vernacular and the homosocial spirit of male camaraderie." And, notably, Ferraro compares Miller with Yezierska: "In a way Yezierska, for instance, never could, Miller here accepts how distant he has become from his bluecollar ethnic heritage" (152). Ferraro is right: Yezierska does not follow a pattern of measured detachment from her ethnic roots. Instead, she discovers their increasing value. For Yezierska, her ethnic heritage permeates all she writes and informs her response to Whitman.

Gentile culture, and not exclusively literature, eclipsed religion as a source of authority for many immigrants. At the start of All I Could Never $B e$ (1932), Yezierska's last published work of fiction before the semi-fictional autobiography Red Ribbon on a White Horse (1950), Yezierska offers the perspective of hindsight as she paints a picture of immigrant clerks, peddlers, tailors, and factory girls aching to discover themselves through the intellectual life of America: "Misfits in the social scheme trying to find where they belonged, following every free lecture on music, painting, poetry, philosophy, or sociology with the same indiscriminate ardour with which their elders followed the exhortations of their rabbis. People in their ignorance worshipping the god of knowledge." ${ }^{6}$ Like these young "misfits" Yezierska retrospectively views with disdain, she was likewise drawn to the god of knowledge and, from what one can gather, was no more discriminating than the immigrant cultural omnivores she disparages. Ingesting the culture of America, 
learning the language that mediated the culture, was the necessary prelude to the conversion from religious to American secular authority. ${ }^{7}$

All I Could Never Be, the title of which comes from Browning's "Rabbi Ben Ezra," also contains the last of Yezierska's various fictional incarnations of John Dewey. As is now well known, Yezierska had had a romantic relationship with Dewey during 1917-1918 that she subsequently transformed through her fiction into a symbolic courtship between the immigrant woman and America, the gentile suitor. ${ }^{9}$ This figure of the suitor first appears in her works as an embodiment of democratic culture, but it gradually hardens into a coldly rational and inflexible stranger, confirming the immigrant woman's sense of her otherness. Invariably an intellectual, the suitor also allows for a comparison between New and Old World males. The New World scholar/thinker in All I Could Never Be resembles her studious, religious father, and she identifies a spiritual connection between the two men: "for all their differences, there was that unworldly look about Henry Scott's eyes that made her feel her father." 10 Henry Scott and her father are but two versions of the life of the mind that Fanya desires for herself, a life denied her by Jewish patriarchy but attainable, it would seem, among the patriarchs of New World opportunity. The tension between Yezierska's Jewish roots and New World culture is also inscribed in this comparison between Fanya's father and Henry Scott. Jewish orthodoxy repels her because it demands a subservience she cannot abide, while New World liberalism, in its detached and rational guise, disappoints her because it invalidates her highly charged emotional being. Ultimately, the secular god of knowledge as represented by the figure of the gentile suitor fails.

In view of the above, it is not surprising that the two American writers who appealed most to Yezierska were Emerson and Whitman, men who denied the authority of authority and praised the individual. While the influence of Emerson on Yezierska has already been investigated by Carol Schoen in her Twayne study, ${ }^{11}$ the influence of Whitman, whose work was equally important as a source of material for Yezierska's "Americanization," remains to be examined. In Whitman, Yezierska discovers a writer whose democratic politics, religious liberalism, and intellectual vitality are matched by the sympathetic warmth of a fully sentient being who, by chance, is also for this immigrant proto-feminist, as "Song of Myself" declares, "the poet of the woman the same as the man" $(L G, 48)$. In what follows, I touch briefly on a range of Yezierska's literary interests, noting the writers she mentions and examining the role of language and literature in some of her early fiction. After these preliminary remarks, I focus chiefly on a comparison between "Mostly About Myself," the introductory sketch in Children of Loneliness (1923), and its key source, Whitman's "Song of Myself."

Anzia Yezierska struggled to establish a cultural identity using the world of words, her own and those of others. In reviews, letters, miscel- 
laneous notes, ${ }^{12}$ and her major published works, she refers to a wide variety of writers, not always American. Some, like contemporaries Zona Gale, Dorothy Canfield Fisher, Amy Lowell, and Gertrude Stein, she turns to for advice or inspiration. Others are more predictable figures for the literary aspirant: Shakespeare, Coleridge, Keats, Shelley, Browning, George Eliot, Oscar Wilde, and Joseph Conrad. She is especially drawn to Emily Dickinson, writing admiringly of both "I am nobody" and "How wonderful to be nobody," obvious choices for the immigrant outsider. Sometimes there is an exciting surprise in her literary interests, such as her enthusiasm for Charlotte Perkins Gilman. Among the British writers admired are Kipling, Galsworthy and Zangwill; among the Americans, Richard Wright, William Faulkner, and Arthur Miller. In New York, Yezierska attended lectures delivered by Theodore Dreiser, Stephen Vincent Benet, and Sherwood Anderson at the Writers' Union, making every attempt to acquaint herself with the current literary scene. She follows European writers as well: Tolstoy and Dostoevsky, of course, along with Hugo, Gorky, Stendhal, and Kafka, while her New York Times reviews of Jewish writers indicate that she was also a keen and knowledgeable follower of Jewish-American writing.

Yezierska, as is now known, was far less "green" an immigrant than the mythology of the East Side tenement Cinderella who sold her Hungry Hearts stories to Samuel Goldwyn would indicate. With the commercial market in mind, she carefully studied American periodical literature to find a place for her work. This serious and deliberate writer wrote to be published. But she also wrote because she craved a voice as well as a vocation, and she understood that reading and writing trained that voice and freed her thoughts from their prison.

Carol Schoen, as I have already indicated, points out the very important influence on Yezierska of Emerson, religious liberal and political democrat. Speculating on the role of John Dewey in introducing Yezierska to Emerson, Schoen writes: “Dewey's own philosophy was derived in part from Emerson and Yezierska was known to have treasured Emerson, although it is not possible to pinpoint the exact date at which her interest developed" (12). According to Yezierska's daughter, Louise Levitas Henriksen, Yezierska "read to herself the urging of Ralph Waldo Emerson on self-reliance"13 sometime around 1907. It is likely that Yezierska read more than "Self-Reliance" prior to her relationship with Dewey, but she probably read Dewey's 1903 essay on Emerson sometime after their meeting in $1917,{ }^{14}$ and still more of Emerson afterwards. Her novel Arrogant Beggar (1927), an indictment of charity work in the ghetto, has for its epigraph a quotation from Emerson about "giving."

In 1920, Yezierska's first book, Hungry Hearts, includes a number of stories that reveal the centrality of literary influence and inspiration. ${ }^{15}$ In "Wings," for example, Shenah Pessah tells sociologist John Barnes 
that Olive Schreiner's book Dreams "lifts me on wings" (6). Barnes takes this typical Yezierska immigrant woman character, with her fierce yearning to learn, to the library. The experience overwhelms her: "When they entered the library, Shenah Pessah halted in awe. "What a stillness full from thinking! So beautiful, it comes on me like music!"'(13). In "Soap and Water," an autobiographical sketch from the same Hungry Hearts collection, literature provides a moment of inspiration while Yezierska links three familiar elements: literature, a new religion, and the finding of America. Yezierska describes an incident from her adolescence that simultaneously stimulated her desire to express herself in language and revealed the frustrating inadequacy of her linguistic resources:

One day, when I was about sixteen, someone gave me Rosenfeld's poem "The Machine," to read. Like a spark thrown among oil rags, it set my whole being aflame with longing for self-expression. But I was dumb. I had nothing but blind, aching feeling. For days I went about with agonies of feeling, yet utterly at sea how to fathom and voice those feelings - birth-throes of infinite worlds, and yet dumb. (73)

She must go to college, she decides, if she is to learn to express herself, an idea that "was like the birth of a new religion in my soul" (73). This desire to find an articulate voice is linked with the finding of America, and the piece ends with a sympathetic gesture on the part of a former teacher that leads the highly autobiographical first-person narrator to conclude with "a song of new life: 'America! I found America"” (77).

Taking up this anxious note regarding language once again in "My Own People," yet another story from Hungry Hearts, Yezierska creates Sophie Sapinsky, a young woman whose life is her writing but who doesn't know if she is any good as a writer: "Whether I can write or can't write-I can't stop writing. I can't rest. I can't breathe. There's no peace, no running away for me on earth except in the struggle to give out what's in me"(99). The end of the story brings with it the discovery that Sophie must look for inspiration neither within herself nor in literature, but in her people: "At last it writes itself in me! . . . It's not me-it's their cries - my own people - crying in me! . . t till all America stops to listen"(107). She moves here a bit closer to Whitman.

Yezierska's daughter notes that her mother used Whitman for recitation exercises when taking drama school lessons after winning a scholarship to the American Academy of Dramatic Arts in 1907 (Henriksen, 19-20). She had certainly read a good deal of Whitman by the time she published Children of Loneliness, her second volume of short stories, in 1923. "Mostly About Myself," the introductory piece in Children of Loneliness, is strongly influenced by Whitman both stylistically and thematically. Its very title points to Whitman's "Song of Myself." Yezierska echoes Whitman in what appears to be a deliberately imitative attempt to explore the ideas, diction, rhythm, and images of a writer she obvi- 
ously finds quintessentially American and, not by chance, politically congenial. Like Whitman, Yezierska begins with the personal pronoun "I" and celebrates the self in order to celebrate her people and her oneness with them. Through her, she writes in "Mostly About Myself," the voice of her people speaks itself: "all those dumb generations back of me, are crying in every breath of every word that itself is struggling out of me" (132) or as Whitman puts it in "Song of Myself," "Through me many long dumb voices, / Voices of the interminable generations of prisoners and slaves," 16 voices of despair. The Jewish people, Yezierska records in the same essay, have been deprived of a voice: "For ages and ages, my people in Russia had no more voice than the broomstick in the corner" (131). She wants to speak for them, to untie the immigrant tongue.

One of the most striking of the resemblances to Whitman in "Mostly About Myself" is Yezierska's insistent merging with the mass of her fellow beings. In so doing, she also attempts in her language the alliteration and expansiveness of the Whitman line: "I am the mad mob at a mass meeting, shouting with their hands and stamping with their feet to their leader: 'Speech! Speech!' And I am also the bewildered leader struggling to say something and make myself heard though the deafening noise of a thousand clamoring voices" (132). She is both mob and leader, the many thousand voices and the one. The image is rich, noisy, and unmistakably the result of her creative reworking of Whitman. The rhythm, the phrasing (specifically, the opening repetition of "I am," "And I am"), and the rapid movement from one identity to another are reminiscent of Whitman.

Whitman's expansiveness must also have appealed to Yezierska's own fondness for literary augmentation and development. "Mostly About Myself" presents a series of images of Yezierska's family in lengthy lines that flow one into the other:

My mother who dried out her days fighting at the pushcarts for another potato, another onion into the bag, wearing out her heart and soul and brain with the one unceasing worry-how to get food for the children a penny cheaper-and my father, a Hebrew scholar and dreamer who was always too much up in the air to come down to such sordid thoughts as bread and rent, and the lost and wasted lives of my brothers and sisters and my grandfather and grandmother. ... (131-132)

The focus is trained not on a single individual but on a sweeping panorama of family behind her, invisible to the eye but implied in the long line that recedes back into her Russian past.

The rhythmical iteration found in "Mostly About Myself" is also a rhetorical exercise in imitation, as is the building to affirmation at the end of a passage in which Yezierska grapples with the strongly-felt limitations of her immigrant self: 
I am learning to accept the torture of chaos and confusion and doubt through which my thoughts must pass. . . . I am learning, as I grow older, to be tolerant with my own inadequacy. I am learning slowly to stop wasting myself in trying to make myself over on the pattern of some better organized, more educated person than I. . . . Here I am as I am, and life is short and work is long. With this limited brain of my inadequate self, I must get the most work done. (132-133)

Not only Whitman's alliteration but his internal rhyming is deployed in another passage- "Writing is to me a confession-not a profession"and his rhetorical inversion in another- "the words I write are never what I started out to express, but what come out of my desire for expression" (133). Rhetorical questioning and balanced phrasing, probably derived from Whitman, are additional features of the essay: "What shall I keep, and what shall I throw away? Which is madness, and which is inspiration? I never know" (132).

Yezierska acknowledges her debt to Whitman more than halfway through her essay when she transposes one of his characteristically paradoxical lines: "Whitman has said, 'It is as lucky to die as it is to be born.' And I put his thought into my own words, 'It is as lucky not to have advantages as it is to have them" (139). Like paradox, contradiction, too, draws her attention; she rephrases Whitman's famous line about contradiction when she claims her books are both her and not her: "Is this a contradiction of anything I said in the page above? I do not claim to be logical or consistent. I do not claim to think things out; I only feel out my feelings, and the only thing true about feelings is that they change and become different in the very process of utterance."

With Whitman she had at last found an American ungoverned by the cold hand of logic that Yezierska could not tolerate. With Whitman's exuberance she asserts her vitality and revels in her mutability: "I am alive and the only thing real in my aliveness is the vitality of unceasing change." She even addresses herself in Whitman's familiar self-reflexive manner: "'Anzia Yezierska, get out of your own way,' I cry” (134).

In small and less easily classifiable bits and pieces of "Mostly About Myself," Yezierska recalls parts of Whitman's famous poem. Just as he does "not talk of the beginning or the end" $(L G, 30)$ neither does Yezierska: "With me, the end and the middle and the beginning of my story whirl before me in a mad blurr" [sic] (132). Whitman shamelessly proclaims his egotism: "I know perfectly well my own egotism, / Know my omnivorous lines and must not write any less" $(L G, 77)$. Yezierska is equally alert to her audacious self-regard: "I am aware that there's a little too much of I-I-I, too much of self-analysis and introspection" (133). Similarly, in the sensuous language drawn from the tropes of the body and passion, she once more recalls Whitman. Describing words born of her being that, once on the page, become alien strangers, she writes: "It's as if every kiss, every embrace of the lover and the beloved instead of fusing them into a closer oneness only drew them farther and 
farther apart" (133-134). This is a language dependent upon an accretion of images, a style of writing mined from her reading of Whitman. When she sees beauty everywhere, it is a veritable democracy of beauty: "Beauty was no less in the dark basement of a sweatshop than in the sunny, spacious halls of a palace" (135). Both the sentiment and the antithetical expression of it suggest a practiced imitation in homage to Whitman.

"Mostly About Myself" ends with a celebration of America, an America flawed by commercialism and the gospel of success, but the only country, she contends, where "a dumb thing with nothing but hunger and desire-[would] get the chance to become articulate" (143). In the 1855 Preface to Leaves of Grass, Whitman, too, had praised America as a country that welcomed other peoples and other voices: "The American poets are to enclose old and new for America is the race of races. Of them a bard is to be commensurate with a people. To him the other continents arrive as contributions" ( $L G, 713)$. It is no wonder that Yezierska found in Whitman an overwhelmingly congenial source of inspiration.

Second- and third-generation Jewish writers still found themselves drawing inspiration from Whitman. Bernard Malamud's Oskar Gassner, a fifty-year-old former critic from Berlin and the title character of Malamud's "The German Refugee," speaks of Whitman during his struggle to prepare a lecture on Whitman and German poetry during the summer of 1939. Paralyzed by both his battle with the English language and a dark depression which will ultimately defeat him, Oskar discusses Whitman with his young language tutor, the story's narrator, who tries to help his pupil by reading Leaves of Grass along with the German poets Whitman influenced. Oskar explains to the narrator that what the German poets got from Whitman "was most of all his feeling for Brudermensch, his humanity." 17 Unfortunately, he continues, "this does not grow long on German earth . . . and is soon destroyed" (209). Oskar gives his lecture after the Nazi invasion of Poland, delivering the lines from Whitman's poetry "that all the men ever born are also my brothers, and the women my sisters and lovers, / And that a kelson of the creation is love" $(L G, 33)$. The irony does not escape the narrator, who comments, "Oskar read it as though he believed it. Warsaw had fallen but the verses were somehow protective" (Malamud, 211). Whitman cannot save Oskar Gassner, who takes his own life, but he is clearly of central importance to this Jewish immigrant intellectual.

Marge Piercy, a third-generation descendent of Jewish immigrants, writes of Whitman's influence in "How I Came to Whitman and Found Myself," an essay in which she confesses to finding "in Whitman a confirmation of earlier rhythms from Jewish liturgy and the Torah and Psalms, rhythms that were not those of most poetry I had been taught in school, but rhythms that came more naturally to me." ${ }^{18}$ Like Yezierska, 
Piercy feels that Whitman gave her Jewish self the sense that her life was as "American" as any other: "what I derived from Whitman was permission to be where I was and who I was: to be American, to have a body, which was loud and demanding and altogether wrong, to feel politically, to think that my life, my place and time were worthy of poetry" (456). It is Whitman who helps her to transcend a mid-fifties English department steeped in New Criticism, Pound, Eliot, and Anglophilia.

Moving beyond the circle of Jewish immigrant writers, one can see that Whitman works his magic on non-Jewish immigrants as well. Bharati Mukherjee, the Calcutta-born writer who now lives in the United States, maintains in the introduction to her 1985 book of short stories, Darkness, that it is "possible - with sharp ears and the right equipment- to hear America singing even in the seams of the dominant culture. In fact, it may be the best listening post for the next generation of Whitmans." (Curiously, further in this introduction, she links herself with a Jewish immigrant novel: "The book I dream of updating is no longer $A$ Passage to India -it's Call It Sleep.") ${ }^{19}$ In a more recent example of Whitman's influence, novelist Julia Alvarez, who was raised in the Dominican Republic and emigrated to the United States in 1960, introduces Whitman in How the Garcia Girls Lost Their Accents (1992). Yolanda, one of the Garcia sisters, finds inspiration from Whitman as she prepares a speech to deliver to a school assembly. Like Malamud's Oskar Gessner, the much younger Yolanda freezes, worrying about her accent. She picks up the book of Whitman's poems purchased by her father and is thrilled with her discovery of "a flesh and blood man, belching, and laughing and sweating in poems." When she writes her own speech, with a dollop of plagiarism, she looks at her work and concludes "She finally sounded like herself in English!" ${ }^{20}$ She has to rewrite the speech to satisfy her father, who wants her to be less "boastful" and more respectful, but even with her new speech, there will be no turning back for this aspiring writer who has found Whitman.

Many more examples from both Jewish and non-Jewish immigrant writing could be cited. For the immigrant intellectual and especially the aspiring writer, Whitman gave the sign of acceptance and pried loose the immigrant tongue. In rediscovering the voices of these immigrant writers, some of whose names are little known, we make a mistake to think of their writing as somehow separate from the main canonical line. Anzia Yezierska's search for a literary and national identity brought her strikingly close to the heart of American literary life. Here she found Whitman and through him a voice for immigrant America.

Saint Mary's University, Halifax 


\section{NOTES}

1 Alice Wexler, Emma Goldman, An Intimate Life (New York: Pantheon Books, 1984), 275.

2 Michael Gold, "Ode to Walt Whitman," in Walt Whitman, The Measure of His Song, ed. Jim Perlman, Ed Folsom, and Dan Campion (Duluth: Holy Cow! Press, 1998), 171.

3 Irving Howe, World of Our Fathers (New York: Harcourt Brace Jovanovich, 1976), 430.

4 Thomas J. Ferraro, Ethnic Passages, Literary Immigrants in Twentieth-Century America (Chicago: University of Chicago Press, 1993), 128.

5 Walt Whitman, Leaves of Grass, ed. Sculley Bradley and Harold W. Blodgett (New York: Norton, 1973), 29 [hereafter LG]; see Ferraro, 152.

6 Anzia Yezierska, All I Could Never Be (New York: Brewer, Warren, and Putnam, 1932), 27.

7 Abraham Cahan describes a species of this conversion in his The Rise of David Levinsky. A dictionary and a copy of Dickens's Dombey and Son decisively alter Levinsky's path: "That volume of Dickens proved to be the ruin of my push-cart business" (Abraham Cahan, The Rise of David Levinsky [New York: Harper and Row, 1917], 138). Later, City College becomes Levinsky's adopted place of worship; it was, he pointedly explains, "the synagogue of my new life. Nor is this merely a figure of speech: the buildings really appealed to me as a temple, as a House of Sanctity, as we call the ancient Temple of Jerusalem" (Cahan, 169).

8 Rose Kamel notes that the title All I Could Never Be comes from Browning's lines "All I could never be, / All men ignored in me, / That I was worth to God" in her essay “"Anzia Yezierska, Get Out of Your Own Way': Selfhood and Otherness in the Autobiographical Fiction of Anzia Yezierska," Studies in American fewish Literature 3 (1983), 44. William Lyon Phelps records a 1932 letter from his friend Yezierska, written after the publication of All I Could Never Be, in which she explains that she "was a prisoner of an experience from which I could not escape till I saw Browning's lines [from "Rabbi Ben Ezra"]" (Autobiography with Letters [New York: Oxford University Press, 1939], 907). Her "experience" was an inability to write the required report following work on the John Dewey study of Polish immigrants. The response of the other members of the research group, all of whom were academics, was, she remarks in the letter, "so unreal, so lacking in heart and feeling. But I was too inarticulate to formulate a better way" (Phelps, 906).

9 Yezierska fictionalizes the relationship with Dewey in "To the Stars" (Children of Loneliness, 1923), "Wild Winter Love" (The Century Magazine, February 1927), All I Could Never Be (1932), and Red Ribbon on a White Horse (1950).

10 Yezierska, All I Could Never Be, 35. All I Could Never Be also contains the following description of Henry Scott [John Dewey]: "He was like Moses, Isaiah who lifted multitudes to the heights by the force of their prophecies" (31).

11 See Carol B. Schoen, Anzia Yezierska (Boston: Twayne, 1982), 12, 24, 73, 81, and 94 .

12 See Anzia Yezierska Papers, Department of Special Collections, Boston University Libraries (Mugar Memorial Library). 
13 Louise Levitas Henriksen, Anzia Yezierska, A Writer's Life (New Brunswick: Rutgers University Press, 1988), 19-20.

14 She would surely have noted with approval John Dewey's remarks in his 1903 "Ralph Waldo Emerson" that, "To Emerson, perception was more potent than reasoning" (The Philosophy of Fohn Dewey, ed. John J. McDermott [Chicago: University of Chicago Press, 1973], 25). It is a remark she doubtless would not have made of Dewey himself. She probably also read Dewey's 1891 "Poetry and Philosophy," reprinted in 1929 as "Matthew Arnold and Robert Browning."

15 Sophie Sapinsky, a character from Hungry Hearts, suggests that Yezierska had debated the question of literary imitation. In "My Own People," Sophie wonders about calling her essay "Trust Yourself": "But if I say, 'Trust Yourself,' wouldn't they think that I got the words from Emerson?" (How I Found America, Collected Stories of Anzia Yezierska [including Hungry Hearts, Children of Loneliness, and uncollected stories], New York: Persea, 1991), 100.

$16 L G, 52$. In this connection, Jo Ann Boydston has identified one of Dewey's poems in the introduction to her edition of The Poems of Fohn Dewey that is strikingly reminiscent, in its sentiment, of the respective Yezierska and Whitman passages referring to "dumb voices." According to Boydston, the untitled poem with the first line "Generations of stifled words reaching out" is one of at least two of Dewey's poems shown to Yezierska (The Poems of fohn Dewey [Carbondale: Southern Illinois University Press, 1977], xvii, n. 16). Yezierska reproduced part of it (seven out of twenty lines) with slight alterations (e.g., she changes "unutterable" to "unuttered") in All I Could Never $B e$, having Henry Scott, the character based on Dewey, send it to Fanya, who will be a voice for her people:

Generations of stifled words, reaching out through you

Aching for utterance, dying on lips

That have died of hunger,

Hunger not to have, but to be.

Generations as yet unuttered, dumb, inchoate,

Unuttered by me and mine

In you I see them coming to be . . . . (All I Could Never Be [New York: Brewer, Warren, and Putnam, 1932], 43)

The second of Dewey's poems to which Boydston refers, similarly untitled, was reproduced in Yezierska's Red Ribbon on a White Horse and begins, "I arise from the long, long night" (Yezierska, Red Ribbon on a White Horse [London: Virago, 1987], 111112).

17 Bernard Malamud, "The German Refugee," Idiots First (New York: Farrar, Straus, 1950), 209.

18 Marge Piercy, "How I Came to Whitman and Found Myself," in The Measure of His Song, 456.

19 Bharati Mukherjee, introduction, Darkness (Markham, Ontario: Penguin, 1985), 3.

20 Julia Alvarez, How the Garcia Girls Lost Their Accents (New York: Plume, Penguin Putnam, 1992), 142. 